\title{
THE EFFECTS OF PERFORMANCE APPRAISAL ON EMPLOYEE RETENTION: A COMPARISON OF FINNISH AND VIETNAMESE ENTERPRISES
}

\author{
Nguyen Ha Thu ${ }^{*}$ \\ ${ }^{a}$ The Faculty of Economics \& Business Administration, Dalat University, Lamdong, Vietnam \\ Article history \\ Received: July $24^{\text {th }}, 2016$ | Received in revised form: November $05^{\text {th }}, 2016$ \\ Accepted: November $16^{\text {th }}, 2016$
}

\begin{abstract}
This research aims to identify the features of a performance appraisal system and explore how each feature affects the employees' loyalty. Furthermore, the study would like to discover if these effects are different in different cultures. The author applied qualitative method, and the data were collected through 15 semi-structured interviews (including 7 cases conducted in Finland and 8 cases interviewed in Vietnam). Participants chosen for the research were knowledgeable employees working in Vietnamese or Finnish original enterprises. Four features of a performance appraisal system, which are goal setting, supervisor - subordinate relationship, rewards linked with performance result and fairness issue are argued based on literature review. From empirical studies, a variety of findings is identified supporting and supplementing for existing theories. One of those is the emphasis of self-development based performance appraisal in Finland and the rewarding based one in Vietnam. The performance appraisal system has weak impact on Finnish employees' loyalty; while it does influence Vietnamese individual intention to leave the job. The findings also illustrate that Finnish staff take clear goal setting and fairness as prerequisite features of a performance appraisal; Vietnamese employees, in contrast, view the relationship with supervisors and rewards received as more significant criteria. This study provides suggestions of retaining talents for managerial practices. Findings of the research could assist international managers to concentrate on features which strongly affect the employees' satisfaction and loyalty when they design and implement performance appraisal system in different locations.
\end{abstract}

Keywords: Employee retention; Fairness issue; Goals setting; Performance appraisal; Relationship with supervisor; Rewards.

\section{INTRODUCTION}

In a long history of human resources research, performance appraisal (PA) is mentioned in different perspectives and approaches. Chiang and Birtch (2010) defines a PA is "an objective, rational, and systematic way" containing a communicative process and commitment between organizations and the employees such as feedback, reward, 
equity to manage and enhance the workforce performance. Tziner, Joanis, and Murphy (2000), on the other hand, suppose a PA system as a developmental tool, which focuses on rating scale formats, to reach two purposes: (1) Assisting employees to recognize their strengths and weaknesses for individual improvement; (2) Referring to a reward, inner transfer or demotion decisions. Through this process, employees could know the rewards if they achieve the goal setting, and the consequences if they perform poorly in their assignments and how they can improve their working productivity. Consequently, PA system as one of the HR practices has been introduced and become one of the sustainable competitive advantages of many multinational firms (Gruman \& Saks, 2011).

Theoretically, an effective performance appraisal system could enhance the quality of organizational as well as individual performance through the two-way communication of setting goals and receiving feedbacks, by which the organization could diagnose the problems in personal working and plan the solutions (Murphy \& Cleveland, 1995). Furthermore, improving employees' performance would lead to an increase in their satisfaction and their commitment with the firm, or in other words, this makes employees trust, engage and be loyal with what the corporate expects them to do (Kuvaas, 2011; Mayer \& Davis, 1999; Murphy \& Cleveland, 1995). However, the truth is less than one third of employees believe that their companies' appraisal process could help to improve their performance or their working efficiency (Gruman \& Saks, 2011). With the same opinion, Latham, Almost, Mann, and Moore (2005) stress that the outcome of many performance appraisals is frequently a decrease rather than an increase in performance. Hui and Qin-xuan (2009) also indicate that regardless of the significance of performance appraisals in corporate management, this process is still not welcomed by the employees. There are many explanations for this phenomenon: For example, differences in culture in which the ways of conducting the appraisal might be not familiar with some local units (Evans et al., 2011). Another problem may be the stress, conflict and organizational political behavior derived from the managers/appraisers who are subjective in evaluating their employees (Hui \& Qin-xuan, 2009). Furthermore, the appraisal designs may not be clear and the feedback might be much more destructive than constructive (Latham et al., 2005). 
These issues obviously affect the satisfaction and the engagement of the employees towards organizations in various levels. However, the question whether these factors influence employee retention has not been widely addressed among research in this field. In addition, the research would like to discover that among above-mentioned factors affecting a performance appraisal system, which one has the most dramatic influence on the employees' decisions in staying and devoting for the company or leaving and seeking for another opportunity in another firm. Moreover, the research also concerns about whether these effects are the same in every corner of the world, or they are different from different nations, values and cultural behaviors, especially in Western and Eastern countries. Therefore, findings of the research could be useful suggestions for international managerial practices in general and HR practices in particular in managing people in distinguishing cultures effectively, especially for multinationals when designing a suitable performance appraisal system for each location.

In short, this study fullfills three purposes. First, it identifies determinants of a performance appraisal system. Second, it discovers the main differences between performance appraisal systems in different cultures. And last, it studies the effects of each characteristic of the performance appraisal system on employee retention in Western and Eastern countries, for which Finland and Vietnam are chosen to do research since these two countries could demonstrate two reverse cultures.

\section{DETERMINANTS OF A PERFORMANCE APPRAISAL SYSTEM}

\subsection{Goals setting}

It is widely accepted that goal setting is the first step of any strategies and plays a fundamental role in management. In PA process, goal setting is considered as the heart of the whole system (Smith \& Brouwer, 1977, p. 77). The objective of this activity is that employees could understand clearly their roles and responsibilities in the organization, how they are scored for each performance, which are clear guidelines and direction for work tracking so that the employees do not get lost and ambiguous about what and why they have to do in the corporate. However, goal setting is not the one-way communication from corporate to its employees. Goal setting session is an opportunity for both the 
company and its employees to discuss and share the company's demands and the individual expectations in each period of work; and after the negotiations and discussions, they could compromise an agreement for the same objectives (Smith \& Brouwer, 1977).

\subsection{Relationship between supervisors and their subordinates}

Prior studies have emphasized the strong influences of supervisors-subordinates relationship on the PA outcomes, such as job satisfaction, working commitment and loyalty (Deluga, 1998; Elicker, 2006). In terms of leader - member exchange theory, the in-group members or the employees with high quality relationship with their supervisors have higher chances to raise their voice in the PA session (Elicker, 2006). Since the ingroup employees are more confident in communicating with their managers, they could clarify and resolve their problems as well as discuss about their expectations. Therefore, the feeling of justice is easier to perceive (Elicker, 2006).

The question is that how to build a high-quality supervisor - subordinate relationship. As figured out in leader - member exchange theory, the quality of this relationship is contributed by both material and non-material exchanges to enhance the mutual benefits (Golden \& Veiga, 2008). The leaders could offer the invaluable information, the attractive tasks and positions, the developmental trainings, the interesting challenges, the extra break-time days or the increased salary and bonus. In return, the employees would express the motivating working attitude, the loyalty or the high respect (Golden \& Veiga, 2008).

As leader - member relationship is subjective, a high-quality relationship could be built by different exchanges, depending on different individuals. For instance, some employees expect the material offers (financial incentives, high salary, and complimentary products) to increase their performance whereas others prefer the nonmaterial ones (developmental trainings, childcare, or a holiday trip) to satisfy their needs. In contrast, some employers expect the reciprocation of positive working outcomes and high productivity, whilst others want the respectful behaviors from their followers. These differences could be more obvious in different cultures. 


\subsection{Rewards linked with the performance appraisals}

The linkage between appraisal outcomes and developmental rewards (promotion, internal mobility, financial bonuses, learning opportunities, salary increasing) has a significant impact on improving the employees' satisfaction (Evans et al., 2011). When the PA is tied with promised benefits including either material or non-material rewards, individuals have more motivation to achieve their working targets. Mayer and Davis (1999) proposes that a PA system which clarifies and increases the connection of performance and rewards could enhance the organizational trust, which is the basement of individual commitment and loyalty. The reason could be the consideration of reward as part of psychological contract; thus, to strengthen this contract, the expected and deserved rewards should be allocated. In contrast, if the rewards are not compatible with the employees' expectation, the psychological contract could be broken, resulting in the reduced commitment and working satisfaction. Explaining from the social exchange theory, the employees will continue devoting their efforts for the companies (or remaining the relationship with their firms) when they perceive that the rewards which they receive from their contribution and their working outcomes are deserved. On the contrary, if the employees suppose that the benefits which their enterprises reward them are too small compared with their working, they would seek for another position. Additionally, the rewarding mechanism is only effective if the employees' working results are rated correctly and differentiated. As the objectives of rewarding is to praise staff contribution and encourage them to perform better, a same score rated for every member leading to the same bonus could make talents feel unfair and disappointed (Lawler, 2003).

\subsection{Fairness of the performance appraisal}

Fairness is proved to affect various organizational outcomes such as trust and commitment, job satisfaction, working performance or withdrawal (Colquitt et al., 2001; Sholihin \& Pike, 2009). However, fairness is a sensitive and subjective issue. Different people perceive fairness differently. Many employees think that they are being evaluated by the appraisers, normally their supervisors, who lacks objectivity and sometimes they are being evaluated by a person who does not understand deeply their roles and their tasks, and hence it is not fair (Latham et al., 2005; Narcisse \& Harcourt, 2008). 
In order to explain the level of fairness, the equity theory could be applied. From the equity theory, the individuals compare their input-output ratios with their colleagues to conclude the degree of fairness/justice; So in performance appraisals, the employees will compare their self-evaluation to the rating they receive from their appraisers and with others' results (Erdogan, 2002). Jr and McNall (2010) suppose that even the employees receive the negative evaluation; they could accept it as fair if they perceive the interpersonal interactions and informational communications are fair. In Kavanagh and Brown (2007) findings, the justice perception is strongly related with the employees' involvement level in goal setting session, their understanding of PA process and the supervisor's attitude. It means that if the subordinates are interactive and active in communicating in PA discussion and they consider their supervisors as neutral or unbiased, they are satisfied with the PA results.

This study claims that organizational communication, rating results and rewards distribution are interrelated to the quality of supervisors - subordinates' relationship because the supervisors have to involve in every step of the PA process. Therefore, people in the high-quality relationship are more satisfied and justice-perceived than those in the low one.

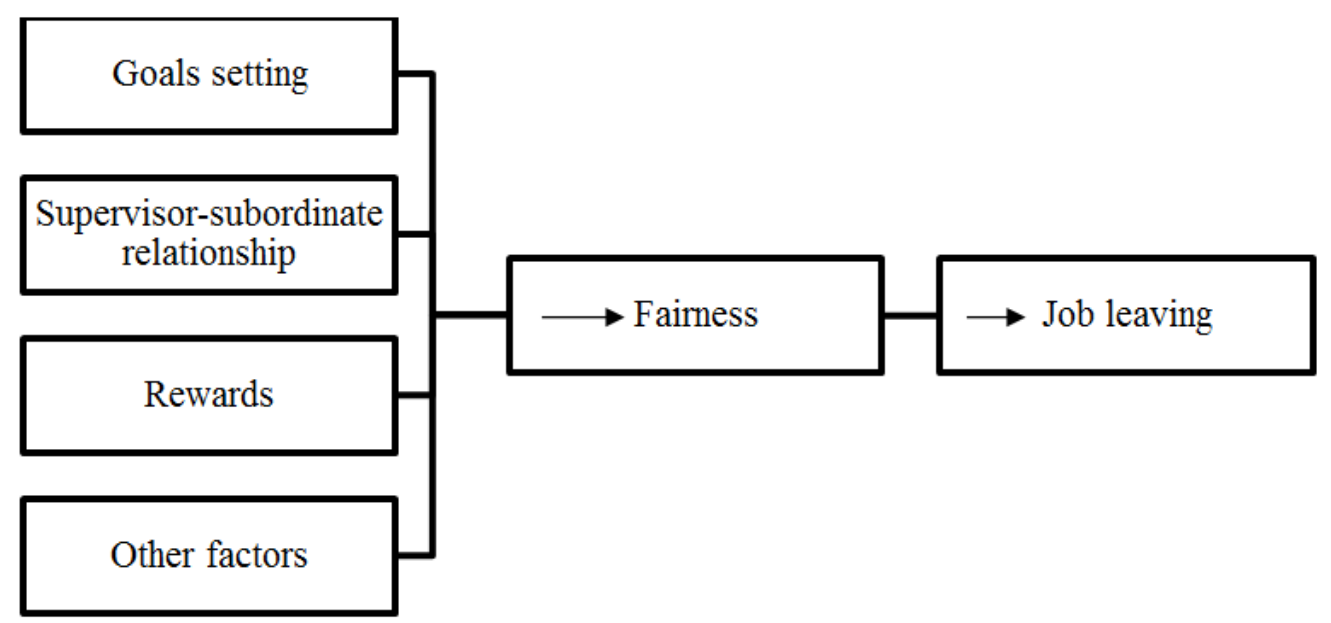

Figure 1. Relationship of PA features and job leaving

Furthermore, from the equity perspective, in the ratios of input and output, the input could be the employees' effort and contribution. The output could be the possibility of interactive communication about the employees' expectations and what they should do 
to achieve them, the treatment of supervisors and the rewards. If one of those three factors is not fulfilled, the unsatisfied or unfair feeling could occur, which is the origin of the leaving intention. Therefore, this study supposes that the perceived feeling of inequality is the main cause of job hopping (Figure 1).

\section{CULTURAL DIFFERENCES IN PERFORMANCE APPRAISAL SYSTEM}

\subsection{Hofstede's cultural dimensions}

From 1968 to 1972, there were approximately 116,000 questionnaires conducted by Hofstede in multinational corporation IBM in 72 different countries (from which 40 countries were initially analyzed) (Hofstede, 1980, p. 11; Hofstede, 2001, p. 41). Based on his findings, Hofstede developed a cultural framework describing effects of a societal culture on the values of its members, which includes four main dimensions: Power Distance; Individualism - Collectivism; Uncertainty avoidance; and Masculinity Femininity (The Hofstede Centre, 2014a; Hofstede, 2001, p. 41). In 1988, the fifth dimension: Long-term versus short-term orientation or the Confucian dynamism was added by a new cross-national study in China (Hofstede, 2001, p. 41; Hofstede \& Bond, 1988). This study utilizes the Hofstede's cultural dimensions as primary foundation for analysis.

\subsubsection{Power distance}

Human inequality is the term appearing in all societies. However, in different cultures, the level of inequality is different. The dimension of power distance refers to hierarchical powers accepted in a society or the unequal power distributed in an institution (Hofstede, 2005, p. 28). In high power distance cultures, since the authority is highly respected and the power is centralized from top managers, the followers are likely to accept and follow all decisions made by their leaders (Hofstede, 2005, p. 37). Moreover, protecting the status of the superiors by hiding negative expressions is one of the recommended rules to prolong the supervisors - subordinates relationship (Chiang \& Birtch, 2010) whereas, in low power distance nations, it is open for individuals to raise their voice to their leaders (The Hofstede Centre, 2014b). 
Applying these assumptions to the PA system, in high power distance countries, it is probably difficult and pressure for the employees having comfortable conversations with their supervisors about their real opinions or feelings. Therefore, the goal setting session could be dominated by the leaders. Furthermore, the subordinates are more likely to passively accept the evaluations and the rewards without any upward feedbacks. However, because of the hierarchical organizational system, the rewards are distributed upon the positions rather than the real contributions and the results (Chiang, 2005). Combined, as mentioned in previous session, the PA needs two-way communication to reduce the misunderstandings. Hence, the probability of a low-quality leader - follower relationship and the unfair perception could occur in these high power distance cultures, leading to the employees' dissatisfaction and then the thought of leaving. On the contrary, in low power distance nations, the mutual communications in PA progress are encouraged, leading to the active participation of employees (Chiang \& Birtch, 2010). It means that the subordinates in low power distance cultures are supported to express their expectations, their ideas as well as their arguments; and thus, their working outcomes and their satisfaction positively increase.

\subsubsection{Individualism versus Collectivism}

The dimension of individualism refers to the bonding degree of an individual towards his society (Hofstede, 2005, p. 51). In individualistic cultures, it is focused on personal achievements, developments and individual rights. People are expected to take care of themselves, their interests and their close families only. Therefore, in this kind of culture, the relationship of supervisors and their subordinates is based on business transaction, which means that a poor performance leading to the firing consequence could be normally accepted (Hofstede, 2005, p. 64). In contrast, in collectivist societies, individuals act as members of a cohesive group and they put the organizational rights as the priority (The Hofstede Centre, 2014b). For the exchange, the group will protect its individuals, resulting in the preferential treatment of in-group members regardless of their working productivity (Hofstede, 2005, p. 64).

With regard to the PA process, in the individualistic cultures, it is regular to differentiate the appraisal results based on employees' performance in order to enhance 
the individual competitiveness (Chiang \& Birtch, 2010). Therefore, the rewards linked with the PA are used to increase the motivation and the material rewards such as financial incentives are more effective (Chiang \& Birtch, 2010; Chiang, 2005). However, in the collectivistic societies, the performance does not refer to the individual working efficiency, but to the whole group outcomes. For which, it is less different in individual appraisal results, and thus, less different in rewards distribution (Chiang \& Birtch, 2010). In addition to the rewards, the non-competitive ones based on experience or tenure are used in this culture to praise the loyalty of group's members (Chiang, 2005). Furthermore, there are differences in judging and rating in PA progress. The first reason is that the collectivistic culture respects "the face", in which direct and negative feedbacks are mostly avoided (Chiang \& Birtch, 2010). The second one could be the relationship of ingroup and out-group employees with their supervisors. Even the in-group members perform poorly, the supervisor still protects them and praises them. Out-group members, on the other hand, are treated by regulations or under-rewarded regardless their efforts or their great achievements. Besides, this study argues that because the PA mostly focuses on the individual performance, it could be considered as unnecessary in collectivistic cultures in which people are rated as the same.

\subsubsection{Uncertainty avoidance}

The dimension of uncertainty avoidance is the extent of tolerance for the unknown situations in a specific community or the degree of willingness to take risks (Hofstede, 2005, p. 113). People in cultures with strong uncertainty avoidance tend to be more emotional. The individuals in these countries will try to minimize the occurrence of unknown and unusual circumstances by carefully planning and implementing rules, laws and regulations as well as showing little tolerance for inappropriate ideas or behaviors. In contrast, people in weak uncertainty avoidance cultures accept the unstructured situations or changeable environments and are flexible with the rules (Hofstete, 2005, p. 125; The Hofstede Centre, 2014b).

Regarding to the PA system, in high uncertainty avoidance societies, the standardized and formalized PA design is preferable (Chiang \& Birtch, 2010). Since the employees are afraid of unpredictable phenomenon, they need the clear guidelines, 
adequate information and frequent communications to reduce the future risks (Chiang \& Birtch, 2010). Therefore, the employees in this culture are motivated by security and certainty, by which justice is perceived with the formal PA and the fixed and nonperformance-based rewards are expected to ensure the future (Chiang \& Birtch, 2010; Hartmann \& Slapničar, 2012; Hofstede, 2005, p. 125). Besides, because people are hesitant to change, they have a tendency to stay in a company for a long time (Hofstede, 2001, p. 169). In comparison, rules and regulations could be flexible in solving problems in low uncertainty avoidance cultures (Hofstede, 2005, p. 125). As rules could be broken, the supervisors - subordinates relationships are based on trust and commitment (Hofstede, 2001, p. 169). Furthermore, since people are less scared of unknow situations, the employees are motivated by achievements, valued by performance-oriented rewards (Chiang, 2005; Hofstede, 2005, p. 125). From this point, it is obvious that people are easy to move to another corporate if they feel unsatisfied with their current job. Besides, since formality is not highly concerned; it is supposed to diverse the PA measurements to make employees percieve the equality (Hartmann \& Slapničar, 2012).

\subsubsection{Masculinity versus Femininity}

In a long accepted concept, men are supposed to be strong, decisive, assertive, competitive and play the lead role in society; whereas women are supposed to be caring and harmonizing (Hofstede, 2005, p. 81). Therefore, the dimension of masculinity is concerned with the gender role issues in a specific culture. According to Hofstede (2005, p. 82), masculine cultures refer to societies in which the social gender roles are clearly distinguished; while feminine ones imply to cultures in which there are overlaps between men and women's roles (i.e., both genders are characterized by being modest and tender). In other words, masculine cultures' values concentrate on competitiveness, assertiveness, materialism, ambition and power; whereas feminine cultures' values stress on relationships and quality of life (The Hofstede Centre, 2014b).

In relation to the PA system, the masculine societies expect the competitions, causing the expectations of differences in rewards distribution ( Chiang, 2005; Chiang \& Birtch, 2010). Moreover, since reward is the evidence of ability affirmation, it is the significant part of PA results' purpose. Higher payment and greater position are highly 
preferable (Hofstede, 2001, p. 318). In terms of PA communication, it is claimed that the employees in high masculine cultures have strong intrinsic belief about their capabilities; therefore, they expect the self-management even they seek for the interactive feedbacks (Chiang \& Birtch, 2010). Whilst in feminine societies, it is valued on cooperation, human relationships and caring to others (Chiang \& Birtch, 2010). The relationship of managers and their subordinates is mostly equal and the problem solving is based on compromise and negotiation (Hofstede, 2001, p. 318). Therefore, the developmental communication is emphasized in working environment (Chiang \& Birtch, 2010). As stress or pressure is avoided in this culture, the employees expect the fewer working hours and the indifferent rewards allocation (Chiang \& Birtch, 2010; Hofstede, 2001). In addition to the reward issues, the feminine-culture employees appreciate the non-material rewards than the material ones. The career break-time or childcare services in order to balance the working - living time and increase the quality of life is expected (Chiang, 2005).

\subsubsection{Short-term versus long-term orientation}

The short-term versus long-term orientation is also named as the Confucian dynamism, which has deeply rooted in a long history of China and affected other neighbors' cultures. Until nowadays, the Confucian lessons are spread among Chinese community, and exist as underlying values of modern Chinese people (Hofstede, 2005, p. 165). This dimension refers to the extent to which people in a specific society take the traditions as priorities when dealing with challenges in present (The Hofstede Centre, 2014b). According to Hofstede (2005, p. 173), people in long-term cultures adapt the past traditions into the present life while the short-term one's respect for the traditions. In the Hofstede (2001, p. 360) findings, leisure time is a significant part of living among shortterm countries; whereas long-term-culture residents consider hard working as more appreciated. Furthermore, as virtue values in the cultural structure of long-term orientation, decision-making and relationship-building are depended upon the moral belief (Hofstede, 2001, p. 366).

From the Hofstede perspective, the PA communication is probably less open in the long-term orientation cultures because as Confucius emphasized on the unequal relationships including leaders and follower's ones, the followers are expected to protect 
the status and the face of their leaders. The praises of loyalty and belongingness could be the great rewards in this culture. In contrast, in short-term orientation ones, the final working results are more concerned and there is separate between business working and interpersonal relationships. The following Table 1 is the summary of main differences in PA system in different cultures as discussed above.

Table 1. Main differences in PA system in different cultures

\begin{tabular}{|c|c|c|c|c|c|}
\hline $\begin{array}{l}\text { Features of PA } \\
\text { Cultural } \\
\text { Dimensions }\end{array}$ & & Goals setting & $\begin{array}{l}\text { Leaders - } \\
\text { Employees } \\
\text { relationship }\end{array}$ & Fairness & Rewards \\
\hline \multirow[t]{2}{*}{ Power distance } & High & $\begin{array}{l}\text { Goal setting } \\
\text { session is } \\
\text { dominated by } \\
\text { the leaders } \\
\text { Indirect } \\
\text { communication }\end{array}$ & $\begin{array}{l}\text { Unequal } \\
\text { No upward } \\
\text { feedbacks to } \\
\text { protect the } \\
\text { supervisors' faces } \\
\text { Passively accept } \\
\text { the evaluations }\end{array}$ & $\begin{array}{l}\text { High } \\
\text { probability } \\
\text { of feeling } \\
\text { unsatisfied }\end{array}$ & $\begin{array}{l}\text { Rewards } \\
\text { are } \\
\text { distributed } \\
\text { upon the } \\
\text { positions }\end{array}$ \\
\hline & Low & $\begin{array}{l}\text { Open and } \\
\text { comfortable } \\
\text { communication } \\
\text { Direct } \\
\text { communication }\end{array}$ & Equal & $\begin{array}{l}\text { Discuss the } \\
\text { PA results } \\
\text { Satisfying } \\
\text { with the } \\
\text { results }\end{array}$ & $\begin{array}{l}\text { Rewards } \\
\text { are } \\
\text { distributed } \\
\text { upon the } \\
\text { outcomes }\end{array}$ \\
\hline \multirow[t]{2}{*}{ Individualism } & Individualistic & $\begin{array}{l}\text { Open and } \\
\text { comfortable } \\
\text { communication } \\
\text { Active } \\
\text { participation to } \\
\text { acquire the } \\
\text { individual } \\
\text { rights }\end{array}$ & Equal & $\begin{array}{l}\text { Differentiate } \\
\text { the appraisal } \\
\text { results } \\
\text { based on } \\
\text { performance }\end{array}$ & $\begin{array}{l}\text { To increase } \\
\text { employees' } \\
\text { motivation } \\
\text { Material } \\
\text { rewards } \\
\text { (financial } \\
\text { incentives) }\end{array}$ \\
\hline & Collectivistic & $\begin{array}{l}\text { Goal setting } \\
\text { session is } \\
\text { dominated by } \\
\text { the leaders }\end{array}$ & Unequal & $\begin{array}{l}\text { Less } \\
\text { different in } \\
\text { individual } \\
\text { results } \\
\text { Differences } \\
\text { in judging } \\
\text { and rating } \\
\text { In-group } \\
\text { members are } \\
\text { protected }\end{array}$ & $\begin{array}{l}\text { Experience } \\
\text { or tenure } \\
\text { rewards } \\
\text { To praise the } \\
\text { loyalty of } \\
\text { members }\end{array}$ \\
\hline
\end{tabular}


Table 1. Main differences in PA system in different cultures (cont.)

\begin{tabular}{|c|c|c|c|c|c|}
\hline $\begin{array}{l}\text { Features of PA } \\
\text { Cultural } \\
\text { Dimensions }\end{array}$ & & Goals setting & $\begin{array}{l}\text { Leaders - } \\
\text { Employees } \\
\text { relationship }\end{array}$ & Fairness & Rewards \\
\hline \multirow[t]{6}{*}{$\begin{array}{l}\text { Uncertainty } \\
\text { avoidance }\end{array}$} & \multirow[t]{3}{*}{ High } & $\begin{array}{l}\text { Standardized } \\
\text { and formalized } \\
\text { PA design }\end{array}$ & \multirow[t]{3}{*}{$\begin{array}{l}\text { Based on rules and } \\
\text { regulations }\end{array}$} & \multirow{3}{*}{$\begin{array}{l}\text { Fairness is } \\
\text { perceived } \\
\text { through } \\
\text { formal PA } \\
\text { process }\end{array}$} & $\begin{array}{l}\text { Motivated by } \\
\text { security and } \\
\text { certainty }\end{array}$ \\
\hline & & $\begin{array}{l}\text { Clear } \\
\text { guidelines }\end{array}$ & & & $\begin{array}{l}\text { Fixed and } \\
\text { non- }\end{array}$ \\
\hline & & $\begin{array}{l}\text { Frequent } \\
\text { communication }\end{array}$ & & & $\begin{array}{l}\text { performance- } \\
\text { based } \\
\text { rewards }\end{array}$ \\
\hline & \multirow[t]{3}{*}{ Low } & $\begin{array}{l}\text { Flexible } \\
\text { problem- }\end{array}$ & \multirow[t]{3}{*}{$\begin{array}{l}\text { Based on trust and } \\
\text { commitment }\end{array}$} & \multirow{3}{*}{$\begin{array}{l}\text { Fairness is } \\
\text { perceived } \\
\text { through the } \\
\text { diversity of } \\
\text { PA } \\
\text { measurement }\end{array}$} & $\begin{array}{l}\text { Motivated by } \\
\text { achievement }\end{array}$ \\
\hline & & solving & & & Performance- \\
\hline & & $\begin{array}{l}\text { Ambiguous } \\
\text { information }\end{array}$ & & & $\begin{array}{l}\text { oriented } \\
\text { rewards }\end{array}$ \\
\hline \multirow[t]{3}{*}{ Masculinity } & Masculine & $\begin{array}{l}\text { Expect the } \\
\text { self- } \\
\text { management }\end{array}$ & Unequal & $\begin{array}{l}\text { Differences } \\
\text { in rewards } \\
\text { distribution }\end{array}$ & $\begin{array}{l}\text { Higher } \\
\text { payment and } \\
\text { greater } \\
\text { position }\end{array}$ \\
\hline & \multirow[t]{2}{*}{ Feminine } & \multirow{2}{*}{$\begin{array}{l}\text { Developmental } \\
\text { communication }\end{array}$} & Equal & \multirow{2}{*}{$\begin{array}{l}\text { Indifferent } \\
\text { rewards } \\
\text { allocation }\end{array}$} & \multirow{2}{*}{$\begin{array}{l}\text { Fewer } \\
\text { working } \\
\text { hours }\end{array}$} \\
\hline & & & $\begin{array}{l}\text { Problem solving is } \\
\text { based on } \\
\text { compromise and } \\
\text { negotiation }\end{array}$ & & \\
\hline \multirow[t]{4}{*}{$\begin{array}{l}\text { Long-Term } \\
\text { orientation }\end{array}$} & \multirow[t]{2}{*}{ Long-term } & \multirow[t]{2}{*}{$\begin{array}{l}\text { Less open } \\
\text { communication }\end{array}$} & \multirow[t]{2}{*}{ Virtue orientation } & \multirow{2}{*}{$\begin{array}{l}\text { Indifferent } \\
\text { rewards } \\
\text { allocation }\end{array}$} & $\begin{array}{l}\text { To praise the } \\
\text { loyalty }\end{array}$ \\
\hline & & & & & $\begin{array}{l}\text { Experience } \\
\text { and tenure } \\
\text { rewards }\end{array}$ \\
\hline & \multirow[t]{2}{*}{ Short-term } & \multirow[t]{2}{*}{$\begin{array}{l}\text { More open } \\
\text { communication }\end{array}$} & \multirow{2}{*}{$\begin{array}{l}\text { Separate between } \\
\text { business working } \\
\text { and interpersonal } \\
\text { relationships }\end{array}$} & \multirow{2}{*}{$\begin{array}{l}\text { Differences } \\
\text { in rewards } \\
\text { distribution }\end{array}$} & $\begin{array}{l}\text { Result-based } \\
\text { rewards }\end{array}$ \\
\hline & & & & & $\begin{array}{l}\text { Material } \\
\text { rewards }\end{array}$ \\
\hline
\end{tabular}

\subsection{Comparisons of PA system in Finland and Vietnam}

In empirical study, Finland and Vietnam are chosen to conduct interviews as these two countries are from distinct cultures: The Western nation and the Eastern one.

As illustrated in Figure 2, there are striking differences in Finnish and Vietnamese cultures in all dimensions. As obviously seen, Finland demonstrates a low power distance 
score (score 33), high individualistic culture (score 63), feminine characteristic (score 26), high uncertainty avoidance intention (score 59) and short-term orientation (score 38). In contrast, Vietnam is a high-power distance country (score 70) with collectivistic culture (score 20), feminine distinction (score 40), weak uncertainty avoidance (score 30) and long-term orientation (score 57). Applying the Table 1 in these scores, it could be guessed that in Finland, the PA communication is more open and direct with high involvement of the employees. Therefore, the Finnish PA system is designed in formal forms with rules orientation to provide clear guidelines, clear information and interactive feedbacks. Moreover, the relationship of managers and their employees are equal and regulationbased, resulting in the separate dividing in the business relationship and the interpersonal one. Since Finland has feminine characteristic, Finnish people focus on the quality of life and expect the security. Thus, financial insurance and working-balance incentives are highly expected. It is predicted that people in Finland rarely consider about changing their job; however, they could leave the company if they have heavy and stressful workload.

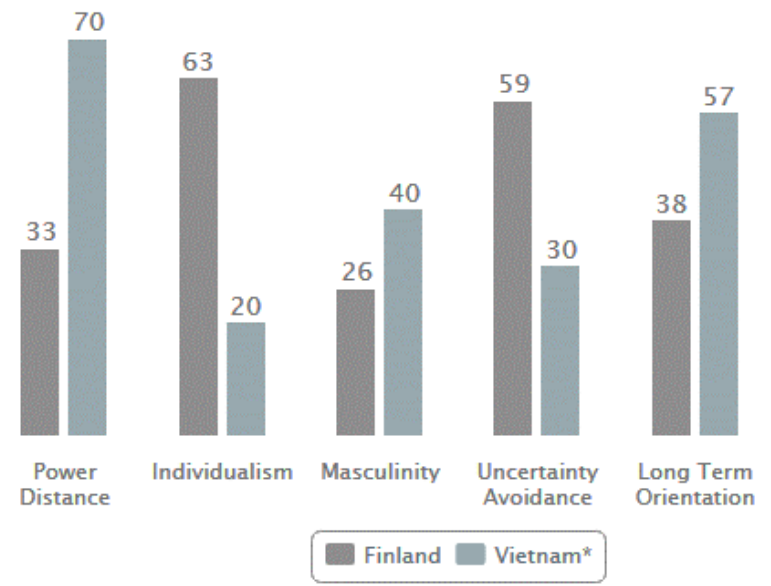

Figure 2. The cultural comparison between Finland and Vietnam

Source: The Hofstede Centre (2014c)

Vietnamese PA system, in contrast, creates less opportunity for employees to comfortably communicate. The reason is that the Vietnamese leaders have dominating roles in a relationship. Therefore, they have the powers to force their followers to implement their desires and treat their subordinates unequally in PA process. Because unequal relationship is one of the features of Vietnamese culture, the out-group members are easily upset with their employers and then easily move. The loyalty of Vietnamese 
employees derives from the feeling of belongingness. However, as Vietnam is the low uncertainty avoidance culture, the employees would like to challenge themselves in different organizations, resulting in the possibility of the high turnover rate.

Although both Finland and Vietnam has the feminine feature, when combining with other dimensions, it could be predicted that the quality of superior - inferior relationship in Finland is enhanced by the interactive communication. Vice versa, in Vietnam, although people focus on the relationship also, but probably in different ways: satisfying and protecting the 'face' of the supervisors. Therefore, arguing with the raters is not expected and accepted.

Table 2. Main differences in PA system in Finland and Vietnam

\begin{tabular}{|c|c|c|}
\hline $\begin{array}{l}\text { Countries Features } \\
\text { of PA }\end{array}$ & Finland & Vietnam \\
\hline Goals setting & $\begin{array}{l}\text { Open and direct communication } \\
\text { High participation of employees } \\
\text { Formal design with clear guidelines, } \\
\text { clear information }\end{array}$ & $\begin{array}{l}\text { Less open communication } \\
\text { Rules could be broken }\end{array}$ \\
\hline $\begin{array}{l}\text { Leaders - Employees } \\
\text { relationship }\end{array}$ & $\begin{array}{l}\text { Equal } \\
\text { Regulation-based } \\
\text { Business and interpersonal } \\
\text { relationships are separate }\end{array}$ & $\begin{array}{l}\text { Leader has dominated role } \\
\text { Status and "face" need to be } \\
\text { protected } \\
\text { In-group members are protected }\end{array}$ \\
\hline Fairness & $\begin{array}{l}\text { Fairness is perceived through formal } \\
\text { PA process } \\
\text { Differences in rewards distribution }\end{array}$ & $\begin{array}{l}\text { Fairness is perceived through the } \\
\text { diversity of PA measurement } \\
\text { Indifferent rewards allocation }\end{array}$ \\
\hline Rewards & $\begin{array}{l}\text { Expect the security } \\
\text { Financial insurance and working- } \\
\text { balance incentives rewards }\end{array}$ & $\begin{array}{l}\text { To praise the loyalty } \\
\text { Experience and tenure rewards }\end{array}$ \\
\hline
\end{tabular}

From the basic theory of Hofstede's cultural dimensions, combined with the Hofstede's research presented in Figure 2, it could be guessed that employees in Finland are more independent, free to express their voices, careful in planning and less competitive than employees in Vietnam. Because of the big gap in cultures between these two countries, there is a potential possibility that the effects of each PA's characteristic on the employees' intention to quit their job could be mostly different in Finland and Vietnam. Table 2 is the outlined summary of Finnish and Vietnamese PA system. 


\section{RESEARCH METHODOLOGY}

\subsection{Methodological approach}

This study utilizes both deductive and inductive approaches since each of them contributes to different parts while doing research. On the one hand, regarding deductive approach, the paper aims to identify the PA characteristics in different cultures based on previous theories and studies. A finalized comparison about PA system in distinguished cultures supposed after analyzing and discussing the literature review is tested in the empirical part. The result of the study is to confirm the theory or to explain the gap between theory and reality. On the other hand, with regard to inductive approach, the interviews are to explore deeply about employees' behaviors towards PA system and its extent of effects on their loyalty. The objective of this exploration is to discover which features of a PA process have strong influence on working turnover to propose suggestions for both further academic research and managerial practices, which is rarely focused in previous research.

\subsection{Research design}

This study applies qualitative method. The reason for this choice is that the research questions are to explore and develop the existing understandings about PA effects on employees' retention. Since there are few papers concerning this matter, the indepth analysis of the research questions is necessary. Combined, the issues emphasized on this research such as fairness are ambiguous; thus, qualitative method is more suitable.

In this study, data were collected through semi-structured interviews. As the research intends to seek out and understand the new employees' insights about PA system, the interview's questions could be modified and could vary from each interview. However, given knowledge about PA consequences on employees' behaviors does exist in various studies, a preliminary list of questions could be prepared. In addition to using interviews instead of questionnaires, it is believed that the participants are reluctant to write down the exploratory answers and give sensitive information to a strange person (Saunders et al., 2009, p. 324). As this research prefers open questions while collecting data, the interviews are the most suitable choice. 
In terms of interviewing method, most of the interviews in this study were conducted by arranging face-to-face meetings. Nevertheless, since the data need to be collected in two different countries in a limited period of time, interviewing via Skype is also employed. Moreover, all the interviews were personal ones because of the sensitivity of the research objectives. As the research discusses some issues such as the fairness in working environment, the relationship between employees and their supervisors, and their extents of loyalty in the organizations, it could be difficult for the interviewees to express their real thoughts if there are other participants.

\subsection{Data collection}

Primary data for the study were collected through semi-structured interviews in two countries: Finland and Vietnam, containing two phases. The first one was the screening phase to select the interviewees. The second one was the interviewing phase.

Regarding to the first phase, the interviewees chosen were employees in different kinds of industries and they had to meet three following criteria:

- $\quad$ Being skilled-employees, which means that they must have graduated from universities or colleges

- Working in Finnish or Vietnamese original companies

- Having participated in PA system in their companies

The targeted interviewees were contacted through personal network and were preliminarily screened by informal conversation. Those who fulfilled all three abovementioned criteria and live in Vaasa or Hochiminh City were asked to arrange a personal appointment in a private space (self-study room in university's library or cafeteria) for the interview. Because of the differences in geographical distance, others living in other cities were asked to participate in the Skype interviews. Among all the interviewees, there were three cases interviewed via Skype (one in Finland and two in Vietnam).

From the screening phase, a total of 15 participants were chosen, including 7 cases in Finland and 8 cases in Vietnam. Unintentionally, all the participants' ages were from 
25 to 30, demonstrating the young labor in two selected societies. The interviews in Finland were conducted first in November 2014 within one week; and then Vietnamese employees were interviewed later in January 2015 due to the travelling plan of researcher.

Given the sensitivity and privacy of the research questions, all the interviews were arranged in the quiet and private space. In Finland, rooms in library and university of Vaasa were booked to proceed the interviews since all the interviewees living in Vaasa were familiar and comfortable with these rooms. In Vietnam, café space was the preferential choice because all kinds of meeting, even business appointment normally happened in a coffee shop. However, café with loud music and narrow space were ignored; Only private corners were chosen for making appointments to reduce the external effects (such us noise, other people) on the interviewees' answers.

At the beginning of each interview, a brief introduction about the research concerns and the affirmation of keeping personal data confidentially were represented; and the using of recorders was asked for permission. Although this research focuses on the effects of PA features on the employees' intention to quit their jobs, the interviewees were not introduced about the research questions. They were only asked to answers the questions related to their PA system. The reason was to avoid the biased thinking so that the real insights could be explored.

While collecting data, all the interviews were both audio-recorded and noted in handwriting. The languages for the interviews were English and Vietnamese, in which English was used for interviewing in Finland and Vietnamese was used in Vietnamese cases. The length of each interview was approximately 30 to 45 minutes. In some interviews, the interviewees provided relevant documents and extra information such as form of PA, the criteria of rating, the general policies and objectives of PA system. These supplement documents were sent to the researcher via email.

After the first interview, the preliminary questions were reviewed and modified for the upcoming meeting. Especially, in Finland, because the language used was English, some terms and explanations were necessary to clarify and confirm to reduce the misunderstandings. Therefore, the language problems were revised after every interview 
to make a better preparation. In Vietnam, language was not problematic since the researcher is Vietnamese. However, the questions of the interview were still reviewed regularly after each interview to add further exploration.

Furthermore, after every interview, by reading hand-writing notes and listening to audio-records, a transcription was immediately transcribed in full text with highlighted important points and saved in a separate word-processed file, as recommended in Saunders et al. (2009, p. 485) research.

\subsection{Data analysis}

Data collected from Finnish and Vietnamese employees were processed separately before making comparisons. The contents of each interview were deeply examined to figure out the implications explaining the phenomenon. It means that each answer was analyzed, divided into small parts and put into different categories. Commonly, since the question was clearly categorized, the full answer of that question is also categorized in the same category. However, as the interviews were semi-structured and the interviewees' responses could be extended to another issue or overlapped with other parts, dividing answers into small sub-answers was necessary. Afterward, a comparison between employees' behaviors in Finland and Vietnam was highlighted and applied back to the proposed PA system to identify if the interviews' results support for the literature arguments. A discussion and explanation of these results and comparisons were analyzed then.

\section{ANALYSIS AND DISCUSSION}

\subsection{Interviews' results}

\subsubsection{Finnish interviews' results}

PA system in Finland is designed in a formal and normative procedure which is regularly conducted once a year. It is slightly different in operating this system in different companies. All the employees are informed fully about how the PA is processed and they are assessed from various sources, including the raters, other team leaders, the cocolleagues and the statistic results. Thus, the PA result is believed to reflect correctly the 
employee's ability and working efficiency. Furthermore, the PA is emphasized by the self-development aspect; Therefore, PA is a chance to discuss what the upcoming work should be and how to improve the individual effectiveness. As a result, there is no pressure when participating in PA discussion. Regarding to the supervisor - subordinate relationship, the employee considers it as a part of work which is regulated by rules and working performance. Therefore, a personal relationship with the boss could not affect the final rating of each employee. Since the real outcomes are appreciated, the same results for everyone are not accepted. However, no reward is expected as the employees explain that a system for rewarding is abnormal and if there are financial incentives, high tax policy will make it become almost indifferent with having the regular income. All the employees confirm that the PA has no effect on their loyalty. None of them has the intention of seeking out a new job. As long as their job is not too stressful and too boring, they stay with their companies.

\subsubsection{Vietnamese interviews' results}

PA systems are designed differently in different companies. Normally, PA is conducted one or two times a year in either formal or informal procedure. In Vietnamese employees' perspective, PA is a process to assess the staff abilities in order to distribute rewards or punishments. Therefore, it is a motivational tool to push the employees to work harder and achieve higher. Increased salary, financial bonuses and challenging tasks are common expectations since they could fulfil the feeling of being recognized and respected. Some other employees suppose that PA is just a procedure of human resource department and has no relation with working performance. Nevertheless, the PA result still affects their financial benefits. In Vietnamese working environment, relationship with supervisors is considered as a significant part. This relationship is not only based on jobs and responsibilities, but also overlaps with the personal relationship. There is a gap between status of supervisors and their subordinates. This gap could vary from case to case, leading to the extent of possibility for employees to involve in PA discussion. The communication could be open and constructive or one-sided and manipulated. However, regardless of how small this gap is, respecting and protecting "face" of the managers are compulsory. Having good relationship with supervisors could bring many advantages. 
For instance, the supervisors could ignore the mistakes and organizational regulations when rating an employee. In other words, building a strong relationship with manager is the synonym of building a strong protection for the employees at working place.

Fairness issue in PA process is another matter with diversified insights. A PA is considered as fair if it is transparent and published among employees. However, when PA result is rated by subjective supervisors, it could not be fair. There are some opinions that as PA is not important, it is hard to perceive it as equal or unequal to every member. Employees who take part in an administrative PA process believe that PA has no effect on their work in every aspect, including leaving decision. In contrast, employees who participate in formal PA discussion claim that PA does affect the loyalty. Specifically, if they receive negative PA results, or have bad relationship with their supervisors or are under-rewarded in comparison with their contribution, they will take the job moving into consideration. The interesting point is that these employees always have intention of working in another place no matter what they satisfy with their companies or not.

\subsection{Comparison and discussion of Finnish and Vietnamese interviews' result}

As described above, it could be obviously seen that there are numerous differences in Finnish and Vietnamese employees' insights in all aspects explored. Only two similarities are discovered. Firstly, all employees, both in Finland and Vietnam, appreciate the different rewards allocated. Nevertheless, Finnish people consider different rewards as a fair issue. Since fairness is perceived when the performance outcomes are rated correctly based on real performance; The rewards based on performance should be differentiated correctly. In Vietnam, employees feel being respectful by receiving higher rewards than others. In other words, higher rewards mean that the organizations understand and praise their contribution as well as consider them as important employees. Secondly, fairness is perceived through diversified assessment, such as the raters, the cocolleagues and the statistical data. However, while Finnish employees totally trust their companies about fairness issue although they do not know other results; Vietnamese ones need the transparency and publishing of all members' results. 
Besides, while employees in Finland share more similarities of behaving towards PA perception; Those in Vietnam present their behaviors and thinking differently in most of questions. The reason could be the PA system in Finland is designed in relatively similar methods in most of companies. In Vietnam, each organization has its own way to implement PA process; Resulting in different PA perceptions and reactions. However, eight Vietnamese interviewees still demonstrate the same cultural insights in their working styles and assumptions.

Specifically, Finnish employees view PA as a chance to improving individual performance and discussing the appropriate solutions for a problem; While in Vietnam, PA is considered as an assessment tool for staff ability and the key to rewarding the organizational members. These understandings are not created from the employees own knowledge. They are presented to the newcomers by human resources department and normally are published throughout the whole organization by formal documents. As presented in introduction, a PA system has two purposes which are enhancing the employees' working productivity and motivating them by distributing rewards. It seems that Finnish companies focus on the former, whereas Vietnamese firms concentrate on the latter. These mindsets have significant impacts on employees' behaviors regarding PA participation. When paying attention to rewarding aspect, Vietnamese employees are under pressure of achieving accomplishment. In Finland, because of considering PA as a self-development tool, the employees are more comfortable in finishing tasks. They do not need to compete with any colleagues. They just improve their working for themselves. Therefore, it is less likely that leaving job is affected by PA in Finland. Vietnamese case is opposite. As PA results influence the individual benefits, there is a high possibility of PA system impacting on employees' retention.

Regarding goals setting, relationship with supervisor, rewards and fairness issues, Finnish and Vietnamese employees demonstrate contrasting thinking, which reflects the national cultural characteristics. The research findings considerably support for propositions concluded by applying Hofstede cultural dimensions to PA features (Tables 1 and 2). 


\subsubsection{Goals setting}

From the interviews, Finnish employers encourage their staff to actively participate in PA process, especially in PA communication. Every employee has an opportunity to discuss and negotiate with their managers about how to improve the job and how to improve their capability. Finnish employees perceive two-way communication as vital part because they need to clarify their tasks and they need to compromise their workload. Following Hofstede's scores (The Hofstede Centre, 2014c), Finland is individualistic and high uncertainty avoidance country. Therefore, people live for themselves, fight for their rights and work based on regulations. In other words, they do not expect the ambiguity in their job. Clear responsibilities and clear guidelines are necessary. Moreover, Finland is also a feminine nation, where the quality of life and nonstressful work are appreciated (The Hofstede Centre, 2014b). Thus, beside of discussing about yearly targets and self-development, workload and the extent of task challenge are also mentioned in goals setting session.

In contrast, the degree of employees' involvement in PA communication depends upon the supervisors - subordinate's relationship in Vietnam. Employees building good relationship with their managers are more comfortable with PA discussion; Whilst those who lack the closeness with their superiors feel pressured and passively participate in PA. The reason could be explained by Vietnamese score of high power distance (The Hofstede Centre, 2014c). The hierarchical structure has a significant impact on social operation, including business environment. People are taught to respect and follow the elders (The Hofstede Centre, 2014b). Therefore, in the relationship of supervisor - subordinate, supervisor is the person who leads and manipulates the communication. Even in companies with open-minded culture, open communication is still based on inferior's face protection. Moreover, Vietnam is a low uncertainty avoidance country (The Hofstede Centre, 2014c). This fact is clearly represented in PA design. All the corporates implement PA system every year. Some companies conduct the goals setting discussion; some others only request their staff to fill in the PA forms. However, no matter which methods are chosen, the organizational regulations and policies could be ignored when doing PA, depending on managers' decisions. In PA discussion, goals setting and rewards 
are both negotiated. Since the managers have a big or monopoly role in communication, goals are expected to be set from top managers.

\subsubsection{Supervisor - subordinate relationship}

The power distance index has a great influence on leader - member relationship. As Finland is a low power distance country, this relationship is equal. It means that managers and their followers have the equal rights to raise voice. While in Vietnam with high power distance, there is a big gap between supervisor and subordinate status (The Hofstede Centre, 2014b). The research findings are similar with this assumption. Finnish employees do not hesitate to share their opinions as well as their arguments to their managers. They view the relationship with their supervisors as a business matter, which is endured by rules and regulations. Therefore, building a specific closeness with managers is no related to having a good performance rating. In Finnish perspective, the PA result is based on only the real working performance.

By opposite, relationship with managers is an essential and compulsory part of working in Vietnamese office. A person could not work effectively if he does not concern about his supervisor. Vietnam is a collectivistic nation, which means that people live following their group. They feel safe when being considered as in-group members (The Hofstede Centre, 2014b). The research interviews show that creating good relationship with supervisor brings many advantages. For instance, the in-group employees could receive more useful information, more supports and more protection from their managers than out-group ones. This phenomenon leads to the preferential treatments to specific employees or the difference between judging and rating staff. Moreover, the high quality supervisor - subordinate relationship is not only built based on working efficiency, but also by respecting the managers' status and understanding the managers' emotions to make reactions. Therefore, making arguments with supervisors is not recommended. Consequently, a good leader - member relationship normally consists of both business and interpersonal aspects. 


\subsubsection{Rewards}

The research finding of rewarding issue is extremely interesting. Finnish employees do not expect rewards linked with PA result because they suppose that PA is for self-development; It is not for allocating rewards. However, if there are rewards after PA assessment, they prefer the financial incentives. The reason for this thinking is not just derived from the companies' orientation which does not offer rewards in PA process, but the Finnish income taxation. From the interviewees, if they receive a financial bonus, they have to pay tax which is high. Therefore, it is not too much different with having basic salary. PA without rewards hardly motivates employees to work harder and achieve higher targets. The interviews' result illustrates that Finnish staff would like to finish their job completely; However, all of the cases do not intend to work above the organizational demands. Although there is no reward expectation in Finnish case, the finding still supports for the proposition in Table 2. From Hofstede's cultural dimensions, Finland has feminine characteristic. Finnish residents appreciate a balancing life in which the workload is not too heavy and stressful (The Hofstede Centre, 2014b). Workload and dayoffs are not the direct rewards since they could be negotiated in PA discussion. However, as non-stressful responsibility is the priority of Finnish staff, dealing about workload could be considered as dealing about indirect reward.

In Vietnam, rewarding is as important as building relationship with supervisor. Vietnamese PA system focuses on rewards and punishments, which motivate and push the staff to hard working. The good performance results and good rewards are the evidence of being recognized or probably having a good position and good opportunities in organizations, which increases the working status. As previously mentioned, Vietnam has the "face" culture, meaning the status respectability, and has collectivist characteristic (The Hofstede Centre, 2014b). Therefore, reaching a higher status or being considered as "good employee" is significant. Vietnamese employees do not work only for themselves; they perform because of their images in others colleagues. This feature is also reflected in terms of reward types, people who work for companies with experience and tenure rewarding system are satisfied with what they receive even though they hope to be 
rewarded more bonuses. Those who deal with their firms about rewards expect the extra offers after PA assessment.

\subsubsection{Fairness}

Employees in Finland believe that they are treated equally and rated fairly because they have a clear system of assessment. The result does not derive from the raters only, but the multi-sources. Therefore, it is trustworthy. In Hofstede's cultural dimensions, Finland is scored as high uncertainty avoidance (The Hofstede Centre, 2014c). Consequently, formal PA design with clear guidelines is applied, reducing the ambiguity and confusion - main cause of communication misunderstandings. This multi-assessment system when implementing strictly could enhance the clarity and the equality.

Fairness issue in Vietnam is more complex. Similar to Finnish case, Vietnamese employees perceive fairness when they are assessed from various sources. However, they only trust the fairness as soon as the results are published. Because their results are the combination of supervisors' rating, colleagues' opinions and statistic data, if there is one factor rated unequally, the total result is unfair. Regarding to equity theory, people compare themselves with others to evaluate the fairness (Furnham, 2005, pp. 295-296). Nevertheless, Finish employees trust their results even though they do not know others. The reason could be the individualistic and high uncertainty avoidance features of Finland. Finnish people respect organizational rules and they build a business relationship by regulations (The Hofstede Centre, 2014b). As a result, the relationship with supervisors or co-workers could not affect their real performance outcomes. Vietnam is different. As mentioned, the superior - inferior relationship has a major impact on working efficiency, resulting in a high possibility of subjective opinions from managers. Moreover, judging and rating is not the same. In-group members are protected; they could hence receive good rating even their performance is poorly. Furthermore, Vietnam is a collectivistic and long-term oriented nation where the virtue is respected (The Hofstede Centre, 2014c). In experience and tenure rewarding system, the managers have the tendency of rating the same good results for every member since the bad ones could affect the basis benefits (such as salary and yearly bonus). Interestingly, employees in this 
system assume that phenomenon as fair because harming the basis financial benefits of a person is considered as unethical.

\subsubsection{Effects of PA system on employee retention}

The findings demonstrate a very weak impact of PA features on job leaving decisions of Finnish employees and a complicated influence on Vietnamese ones. In Finland, the PA purpose is to enhance the employees' effectiveness without any promised-rewards. Therefore, individuals participating PA process have no pressure. After PA sessions, they feel satisfied, they trust the fairness and they understand the benefits deriving from PA discussion. As argued previously, the perceived feeling of inequality, mainly comprising from the ambiguous and dominated PA communication, subjective raters and under-rewarding, is the main cause of leaving intention. Probably since the Finnish PA systems in all interview cases are fair and are not used for rewarding or punishing purpose, it does not affect the employees' loyalty. However, it is noticed that all these cases have no intention to find another job in the future. They are hesitant of changing and they are satisfied with an appropriate workload.

In Vietnam, the findings are diversified since PA systems are designed differently in different companies. Half of the cases assume that there is no relationship between PA outcomes and their loyalty. All of them work in enterprises with administrative PA system or informal PA design. Although PA results do affect their benefits such as increased salary or financial bonus; however, in their perspectives, PA is considered as a useless procedure of human resource department. After PA assessment, every member is rated the same good result. On the other hand, half of the rest cases affirm the influence of PA on their staying. All these employees agree that rewards are important as they reflect their contribution and their recognition. They will leave the companies if they are underrewarded or the PA outcomes are biased by the raters. Surprisingly, the highlighted point is that all these four interviewees intend to work for a short-term period (two to five years) although they are currently satisfied with their job and their PA system; While the first four cases want to stay with their companies in a long-term. 
In addition to the PA features, the findings also figure out that goals agreement and fairness are most important in PA process in Finland whereas in Vietnam, relationship with supervisor and rewards are considered as more significant.

\section{MANAGERIAL IMPLICATIONS}

This study provides an effective framework for international managers while designing and conducting PA assessment in different cultures, especially in Finland and Vietnam. In Finland, the research demonstrates that employees take goals setting communication and fairness as priorities and perceive PA as a self-development tool. In goals setting discussion, targets, clear guidelines and responsibilities as well as the workload should be negotiated. Finnish employees do not expect rewards; therefore, rewarding is optional based on each situation. However, as Finnish prefer the nonstressful life, non-material benefits such as comfortable working environment, short working hours or day-offs should be taken into account. Moreover, Finnish employees gain trust through clear, objective and multi-assessed system. Thus, the design of PA needs to be formal, understandable and transparent.

In Vietnam, relationship with supervisors and rewarding are chosen as two significant features. Vietnamese employees are more open in communicating with their managers when they have close relationship with them. Therefore, in order to encourage these staff to share their opinions, the leaders are advised to build an interpersonal relationship with them. Interpersonal relationship means that besides business assignments, the supervisors should concern about their employees' personal matters or holding activities outside the companies with their inferiors. In addition to rewarding, financial incentives and promotion are expected. However, since Vietnamese individuals are hard-working for better and higher targets, the managers should actively offer the extra bonus if they achieve an excellent result. Completing the promised rewards only could not comprehensively satisfy the employees.

In both cases, no matter which PA methods chosen, the managers should keep in mind that people expect the differences. In Finland, the different results reflect the 
fairness issue. In Vietnam, the different rewards illustrate the individual recognition of their contribution and ability.

\section{REFERENCES}

Chiang, F. (2005). A critical examination of Hofstede's thesis and its application to international reward management. The International Journal of Human Resource Management, 16(9), 1545-1563.

Chiang, F. F. T., \& Birtch, T. A. (2010). Appraising performance across borders: An empirical examination of the purposes and practices of performance appraisal in a multi-country context. Journal of Management Studies, 47(7) 1-24.

Colquitt et al. (2001). Justice at the millennium: A meta-analytic review of 25 years of organizational justice research. Journal of Applied Psychology. 86(3), 425-445.

Deluga, R. J. (1998). Leader-member exchange quality and effectiveness ratings: The role of subordinate-supervisor conscientiousness similarity. Group \& Organization Management, 23(2), 189-216.

Evans, P., Pucik, V., \& Björkman, I. (2011). Global challenge: International human resource management ( $2^{\text {nd }}$ ed.). New York, USA: McGraw-Hill.

Elicker, J. D. (2006). The role of leader-member exchange in the performance appraisal process. Journal of Management, 32(4), 531-551.

Erdogan, B. (2002). Antecedents and consequences of justice perceptions in performance appraisals. Human Resource Management Review, 12(4), 555-578.

Furnham, A. (2005). The psychology of behaviour at work: The individual in the organization ( $2^{\text {nd }}$ ed.). New York, USA: Psychology Press.

Golden, T. D., \& Veiga, J. F. (2008). The impact of superior-subordinate relationships on the commitment, job satisfaction, and performance of virtual workers. The Leadership Quarterly, 19, 77-88.

Gruman, J. A., \& Saks, A. M. (2011). Performance management and employee engagement. Human Resource Management Review, 21(2), 123-136.

Hartmann, F., \& Slapničar, S. (2012). The perceived fairness of performance evaluation: The role of uncertainty. Management Accounting Research, 23(1), 17-33.

Hofstede, G. (1980). Culture's consequences: International differences in work-related values. California, USA: SAGE Publications.

Hofstede, G. (2001). Culture's consequences: Comparing values, behaviors, institutions, and organizations across nations. California, USA: SAGE Publications.

Hofstede, G. (2005). Cultures and organizations: Software of the mind, intercultural cooperation and its importance for survival ( $2^{\text {nd }}$ ed.). New York, USA: McGrawHill. 
Hofstede, G., \& Bond, M. H. (1988). The Confucius connection: From cultural roots to economic growth. Organizational Dynamics, 16, 5-21.

Hui, L., \& Qin-xuan, G. (2009). Performance appraisal: What's the matter with you? Procedia Earth and Planetary Science, 1(1), 1751-1756.

Jr, P. W. T., \& McNall, L. (2010) Justice perceptions of performance appraisal practices. Journal of Managerial Psychology. 25(3), 201-228.

Kavanagh, P., \& Brown, M. (2007). Understanding performance appraisal fairness. Asia Pacific Journal of Human Resources.45(2), 132-150.

Kuvaas, B. (2011). The interactive role of performance appraisal reactions and regular feedback. Journal of Managerial Psychology, 26(2), 123-137.

Latham, G. P., Almost, J., Mann, S., \& Moore, C. (2005). New developments in performance management. Organizational Dynamics, 34(1), 77-87.

Lawler, E. E. (2003). Reward practices and performance management system effectiveness. Organizational Dynamics, 32(4), 396-404.

Mayer, R. C., \& Davis, J. H. (1999). The effect of the performance appraisal system on trust for management: A field quasi-experiment. Journal of Applied Psychology, 84(1), 123-136.

Murphy, K. R., \& Cleveland, J. N. (1995). Understanding performance appraisal: Social, organizational, and goal-based perspectives. California, USA: SAGE Publications.

Sholihin, M., \& Pike, R. (2009). Fairness in performance evaluation and its behavioural consequences. Accounting and Business Research, 39(4), 397-413.

Saunders, M., Adrian, T., \& Philip, L. (2009). Research methods for business students ( $^{\text {th }}$ ed.). New Jersey, USA: Prentice Hall.

Smith, H. P., \& Brouwer, P. J. (1977). Performance appraisal and human development: a practical guide to effective managing. Massachusetts, USA: Addison-Wesley Longman.

The Hofstede Centre (2014a). National cultural dimensions. Retrieved from http://geerthofstede.com/national-culture.html.

The Hofstede Centre (2014b). Dimensions. Retrieved from http://geert-hofstede.com/ dimensions.html.

The Hofstede Centre (2014c). Finland in comparison with Vietnam. Retrieved from http://geert-hofstede.com/dimensions.html.

Tziner, A., Joanis, C., \& Murphy, K. R. (2000). A Comparison of three methods of performance appraisal with regard to goal properties, goal perception, and ratee satisfaction. Group \& Organization Management, 25(2), 175-190. 


\section{APPENDIX: INTERVIEW GUIDELINE}

\begin{tabular}{|c|c|}
\hline Warm up & Name, age, career, company, job position, and so on \\
\hline \multirow{4}{*}{$\begin{array}{l}\text { General } \\
\text { exploration }\end{array}$} & Do you have PA system in your current company? \\
\hline & How often do you have to do the PA? \\
\hline & Do you think it is necessary to do the PA? Why? \\
\hline & $\begin{array}{l}\text { What are the purposes of the PA in your opinion? How do you understand } \\
\text { these purposes? (from your own knowledge or from your company's } \\
\text { communication) }\end{array}$ \\
\hline \multirow{25}{*}{$\begin{array}{l}\text { Specific } \\
\text { exploration }\end{array}$} & Can you describe the procedure of your PA system? \\
\hline & Goal setting \\
\hline & How do you understand each evaluation criteria? \\
\hline & When do you know such criteria (at the beginning or when doing PA) \\
\hline & Who interprets the goals for you? \\
\hline & Do you feel engaged with these goals? Why? \\
\hline & Does it affect much when knowing the criteria in advance? \\
\hline & PA communication \\
\hline & Which ways of communication your company using to conduct the PA? \\
\hline & Which ways do you feel the most effective? \\
\hline & Have you ever received the negative feedbacks? \\
\hline & How did your supervisor make the negative comments? Is it directly? \\
\hline & How do you feel with the direct negative feedbacks? \\
\hline & Fairness + relationship with supervisor \\
\hline & How is your relationship with your supervisor? \\
\hline & Are you comfortable to communicate with her/him? \\
\hline & Do you feel pressure when discussing the PA result with her/him? \\
\hline & $\begin{array}{l}\text { If you are not satisfied with the PA result, do you ask to her/him or you accept } \\
\text { it? }\end{array}$ \\
\hline & Do you think the PA in your company is fair? Why? \\
\hline & Rewards \\
\hline & Do you receive any promise of rewards relating to PA results? \\
\hline & Does the company keep its commitment? \\
\hline & $\begin{array}{l}\text { Are you satisfied with the rewards? Are they deserved and do they reflect to } \\
\text { your contribution? }\end{array}$ \\
\hline & Do the rewards fit with your expectation? Why? \\
\hline & $\begin{array}{l}\text { Do you expect the different rewards for each individual or the same for } \\
\text { everyone? }\end{array}$ \\
\hline \multirow{6}{*}{$\begin{array}{l}\text { Relationship with } \\
\text { employee retention }\end{array}$} & Are you satisfied with the PA system in your company? Why? \\
\hline & $\begin{array}{l}\text { Does the PA process affect your working efficiency and your satisfaction? } \\
\text { Why? }\end{array}$ \\
\hline & Does it affect to your loyalty? Why? \\
\hline & Which characteristics affect to you the most (rating 4 characteristics) \\
\hline & How long do you think you will stay in this company? Why? \\
\hline & If you intend to quit the job, what could be the most potential reasons?... \\
\hline
\end{tabular}




\title{
TÁC ĐỘNG CỦA ĐÁNH GIÁ HIỆ QUẢ CÔNG VIẸC ĐỐI VỚI KHẢ NĂNG GIŨ் CHÂN NHÂN VIÊN: SO SÁNH GIŨ̃A CÁC DOANH NGHIỆP PHẦN LAN VÀ VIỆT NAM
}

\author{
Nguyễn Hà Thu ${ }^{a^{*}}$ \\ ${ }^{a}$ Khoa Kinh tế và Quản trị Kinh doanh, Truờng Đại học Đà Lạt, Lâm Đồng, Việt Nam \\ "Tác giả liên hệ: Email: thunh@dlu.edu.vn \\ Lich sử bài báo \\ Nhận ngày 24 tháng 07 năm 2016 | Chỉnh sửa ngày 05 tháng 11 năm 2016 \\ Chấp nhận đăng ngày 16 tháng 11 năm 2016
}

\section{Tóm tắt}

Nghiên cưu tập trung phân tích các đặc trung của một hệ thống đánh giá hiệu quả công việc và tìm hiểu mối đặc trung đó tác động lên lòng trung thành của nhân viên nhu thếnào. Ngoài ra, nghiên cứu cũng xem xét các tác động này liệu có khác nhau ở nhũng nền văn hóa khác nhau hay không. Sử dung phuoong pháp nghiên cứu định tính, dũ liệu được thu thập thông qua 15 cuộc phỏng vấn bán cấu trúc (trong đó, bảy cuộc phỏng vấn được tiến hành ở Phần Lan và tám ở Việt Nam). Đáp viên lựa chọn cho nghiên cứu là các nhân viên văn phòng làm việc trong các doanh nghiệp Việt Nam hoạc Phần Lan không có yếu tố nuoớc ngoài. Tù lược sủ nghiên cúu, bốn đặc trung của một hệ thống đánh giá hiệu quả công việc đuoơc sủ dụng để phân tích bao gồm: Thiết lập mục tiêu; Mối quan hẹ quản lý - nhân viên; Khen thuởng; và Tính công bằng. Qua nghiên cứu thực nghiệm, các kết quả đã củng cố và bố sung cho các lý thuyết về quản trị nguồn nhân lực hiện tại. Một trong số đó là sự nhấn mạnh của hệ thống đánh giá nhân viên nhằm phát triển cá nhân ở Phần Lan và hệ thống đánh giá nhân viên làm co sơ cho khen thương ở Việt Nam. Ở Phần Lan, việc đánh giá hiệu quả công việc có tác động không đáng kể đến lòng trung thành của nhân viên, trong khi đó, tác động này là khá lớn đến quyết định thay đổi công việc ở Việt Nam. Nghiên cứu cũng chỉ ra rằng nhân viên công sở Phần Lan cho rằng thiết lập muc tiêu và tính công bằng là hai tiêu chí quan trọng nhất của một hệ thống đánh giá công việc; Ngược lại, ở Việt Nam, mối quan hệ với quản lý và khen thương là hai tiêu chí quan trọng hơn. Nghiên cứu đã đưa ra nhũng gợi ý đối với việc giũu chân nhân viên trong quản lý doanh nghiệp. Kết quả của nghiên cứu có thể giúp các nhà quản lý toàn cầu tập trung vào nhũng đặc trung tác động mạnh đến sự hài lòng và lòng trung thành của nhân viên khi họ thiết kể và thục thi hệ thống đánh giá hiệu quả công việc ở các quốc gia khác nhau.

Từ khóa: Duy trì nguồn nhân lực; Đánh giá hiệu quả công việc; Khen thưởng; Mối quan hệ với quản lý; Thiết lập mục tiêu; Tính công bằng. 